\title{
More about the genus Chaerilus Simon, 1877 in Vietnam and Cambodia, with descriptions of two new species (Scorpiones: Chaerilidae)
}

\section{Еще о роде Chaerilus Simon, 1877 во Вьетнаме и Камбодже с описаниями двух новых видов (Scorpiones: Chaerilidae)}

\author{
Wilson R. Lourenço \\ Вицьсон Р. Аоуренсо
}

Muséum national d'Histoire naturelle, Département Systématique et Evolution, UMR7205, CP 053, 57 rue Cuvier 75005 Paris, France: email: arachne@mnhn.fr

Национальный музей естественной истории, Париж, Франция

KEY WORDS: scorpion, Chaerilus, new species, Vietnam, Cambodia.

КЛЮЧЕВЫЕ СЛОВА: скорпион, Chaerilus, новый вид, Вьетнам, Камбоджа.

ABSTRACT. Two new species of Chaerilus are described from Southeast Asia: C. anneae sp.n. from southern Vietnam and C. kampuchea sp.n. from Cambodia. These new species are compared to the other Chaerilus species known from Southeast Asia and Indonesian islands. This study suggests that different species are not too much distinct morphologically, rather corresponding to micro-endemic populations. Molecular studies, now in preparation, are deemed to bring further evidence to favour or refute this hypothesis.

РЕЗЮМЕ. Описаны два новых вида Chaerilus из Юго-Восточной Азии: C. anneae sp.n. с юга Вьетнама и C. kampuchea sp.n. из Камбоджи. Эти новые виды сравниваются с другими видами Chaerilus, известными и Юго-Восточной Азии и островов Индонезии. Данное исследование предполагает, что различные виды не слишком сильно отличаются друг от друга морфологически, скорее соответствуя узкоэндемичным популяциям. Находящиеся в процессе обработки молекулярные данные должны либо подтвердить, либо опровергнуть эту гипотезу.

\section{Introduction}

The family Chaerilidae, with its single genus Chaerilus Simon, 1877, still remains poorly-known among extant scorpions. This genus was originally created to accommodate Chaerilus variegatus Simon 1877 , a species from Java. Subsequently, several other species have been described from Indonesian islands and nearby geographic regions such as Malaysia and Singapore. The majority of these descriptions were based on very limited material, and on weak and/or unclear diagnostic characters. In many cases they were not properly illustrated, sometimes no illustrations were provided at all! This confused situation led to several cases of misidentification by early authors [e.g. Kraepelin, 1894; Pocock, 1899; Fage, 1933, 1936, 1944].

More recently, attempts to clarify the taxonomic status of several species have been more or less successful. Kovař́k [2000], in a very crude revision of Chaerilus, defined 18 species as valid. He clarified, however, the identity of one population from southern Vietnam which had previously been misidentified by Fage [1933, 1936, 1944] as C. celebensis Pocock, 1894, C. rectinimanus Pocock, 1899 and/or C. variegatus. He also described $C$. petrzelkai Kovařík, 2000. Subsequently, that species was redescribed and illustrated by Lourenço \& Zhu [2008]. C. celebensis was also redescribed and confirmed as an endemic element of the Celebes (Sulawesi) fauna [Lourenço \& Ythier, 2008; Lourenço et al., 2010]. In addition, C. philippinus Lourenço \& Ythier, 2008, C. thai Lourenço, Sun \& Zhu, 2010 and C. spinatus Lourenço \& Duhem, 2010 have been described from the Philippines, Thailand and the Island of Halmahera, Indonesia, respectively [Lourenço \& Ythier, 2008; Lourenço \& Duhem, 2010; Lourenço et al., 2010].

During the last three decades, but especially in the recent years, further new species have been revealed in tropical Asia: C. chapmani Vachon \& Lourenço, 1985 from Sarawak, Borneo, C. sabinae Lourenço, 1995 from Celebes, C. ojangureni Kovařík, 2005 and C. sejnai Kovařík, 2005 from Malaysia, C. laoticus Lourenço \& Zhu, 2008 from Laos, C. vietnamicus Lourenço \& Zhu, 2008 from Vietnam, C. telnovi Lourenço, 2009 from the Moluccas, and C. andamanensis Lourenço, Duhem \& Leguin, 2011 from the Andaman Islands [Vachon \& Lourenço, 1985; Lourenço, 1995, 2009; Kovařík, 2005; Lourenço \& Zhu, 2008; Lourenço et al., 2011].

So far, five species have been described from Laos and Vietnam: C. laoticus from Laos, C. petrzelkai and C. julietteae Lourenço, 2011 from southern Vietnam, 
C. vietnamicus from northern Vietnam, and C. phami Lourenço, 2011 from the Island of Côn Son (Poulo Condore). In contrast, no Chaerilus species have hitherto been recorded from Cambodia [Lourenço \& Zhu, 2008; Lourenço, 2011a, b]. These species belong to two distinct groups, as defined by Lourenço [2011a].

The following species can be retained as valid for the Indonesian Islands and Southeast Asia. However, those marked with an asterisk (*) have not been examined in the present study. These are probably valid species, but better descriptions with proper illustrations are required.

\section{The 'variegatus species-group'}

C. andamanensis Lourenço, Duhem \& Leguin, 2011

C. anneae sp.n.

Chaerilus borneensis Simon, 1880

Chaerilus celebensis Pocock, 1894

C. kampuchea sp.n.

Chaerilus laoticus Lourenço \& Zhu, 2008

* Chaerilus ojangureni Kovařík, 2005

Chaerilus petrzelkai Kovařík, 2000

Chaerilus philippinus Lourenço \& Ythier, 2008

Chaerilus phami Lourenço, 2011

Chaerilus rectimanus Pocock, 1899

Chaerilus robinsoni Hirst, 1911

Chaerilus sabinae Lourenço, 1995

*Chaerilus sejnai Kovařík, 2005

Chaerilus spinatus Lourenço \& Duhem, 2010

Chaerilus telnovi Lourenço, 2009

Chaerilus thai Lourenço, Sun \& Zhu, 2010

Chaerilus variegatus Simon, 1877

Chaerilus vietnamicus Lourenço \& Zhu, 2008

2. The 'truncatus species group'

Chaerilus agilis Pocock, 1899

Chaerilus cavernicola Pocock, 1894

Chaerilus chapmani Vachon \& Lourenço, 1985

Chaerilus julietteae Lourenço, 2011

Chaerilus laevimanus Pocock, 1899

*Chaerilus tichyi Kovařík, 2000

\section{Material and methods}

All type material is deposited in the Muséum national d'Histoire naturelle, Paris, France (MNHN). Illustrations and measurements were made with the aid of a Wild M5 stereo-microscope with a drawing tube (camera lucida) and an ocular micrometer. Measurements follow Stahnke [1970] and are given in mm. Trichobothrial notations follow Vachon [1974] while morphological terminology mostly follows Hjelle [1990].

\section{Taxonomic part}

Chaerilidae Pocock, 1893

Chaerilus Simon, 1877

Chaerilus anneae sp.n.

Figs 1-6.

HOLOTYPE + . Vietnam, Binh Thuan Province, Ta Kou (9C), $670 \mathrm{~m}$ alt., under stone, 13.XII.2006. leg. J. Arabi.
NAME. Honours Anne Bedos (MNHN) for her efforts in collecting scorpions in Southeast Asia.

DIAGNOSIS. A small species compared to other congeners, $18.2 \mathrm{~mm}$ in total length. General coloration reddish-brown, marked intensely with variegated brownish spots. Carapace strongly narrowed towards anterior edge; almost acarinate and moderately granulated; anterior margin weakly emarginate; furrows shallow. Metasomal carinae strongly marked; ventral carinae absent from segments I and II, weakly marked in segment III; lateroventral and ventral carinae in segment $\mathrm{V}$ composed of spinoid granules. Telson pyriform; aculeus weakly curved. Dentate margins of fixed and movable fingers with 9 and 10 rows of granules, respectively. Pectinal tooth count 4-4 (†). Genital operculum plates suboval in shape. Trichobothriotaxy of type B, orthobothriotaxic.

RELATIONSHIPS. C. anneae sp.n. shows especially clear-cut morphological similarities to $C$. petrzelkai, also described from Vietnam. However, the new species can readily be distinguished by the following combination of characters: (i) a darker coloration, in particular in ventral view, with spots over the genital operculum and pectines, (ii) pedipalp chela fingers with 9 or 10 rows of granulations, (iii) metasomal carinae with strongly marked spinoid granules.

DESCRIPTION. Coloration: Basically reddishbrown, but intensely marked with brownish variegated spots. Carapace reddish-brown, with dark spots in central area. Tergites yellowish, strongly marked with dark confluent spots. Metasomal segments yellowish with dark variegated spots. Telson yellowish with dark variegated spots; aculeus reddish. Chelicerae yellowish, intensely marked with variegated spots; fingers blackish; teeth dark reddish. Pedipalps reddish-brown; femur more intensely spotted than patella and chela, blackish; dentate margins of fingers almost blackish. Legs yellowish with brownish variegated spots. Venter and sternites reddish-yellow to reddish-brown; genital operculum and pectines with variegated spots.

Carapace strongly narrowed anteriorly; anterior margin weakly emarginate; almost acarinated and moderately granulated; furrows shallow. Two pairs of lateral eyes, and one pair of moderate median eyes about twice the size of lateral eyes; median eyes anterior to centre of carapace. Tergites moderately to strongly granulated; carinae obsolete. Sternum pentagonal, longer than wide; genital operculum plates suboval. Pectinal tooth count 4-4 (+). Sternites smooth, with a few minute granules on VII; spiracles small and round; carinae absent from VII. Metasomal segments I to III wider than long; segment IV as long as wide; V longer than wide. All carinae strongly granular; ventral carinae absent from segment I; weakly marked in segment II; dorsal and laterodorsal carinae with spinoid granules in segments I-IV; lateroventral and ventral carinae in segment $\mathrm{V}$ composed of spinoid granules. Vesicle moderately elongated, pyriform, almost smooth, with a few granules at base of aculeus; aculeus short 

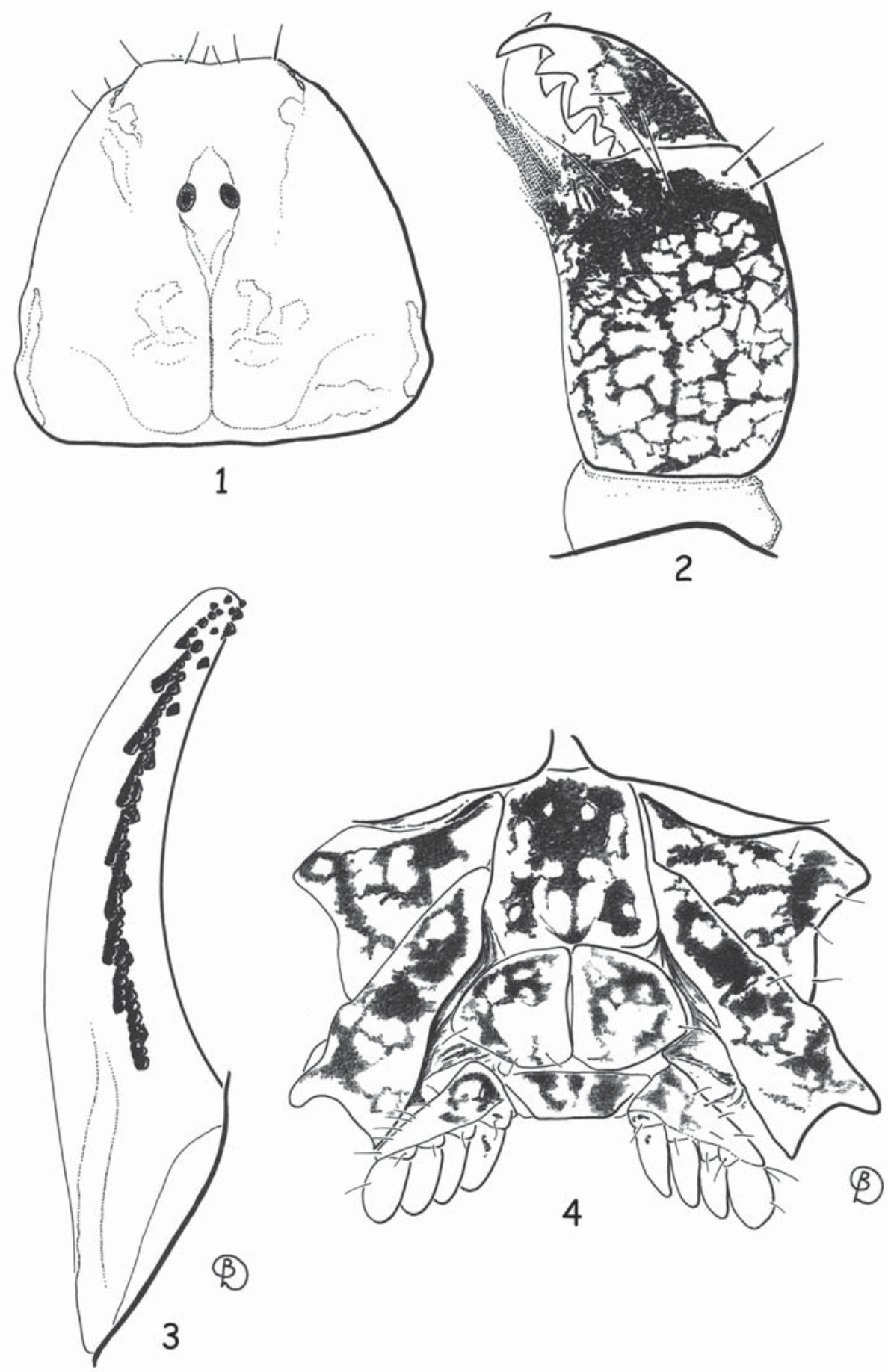

B

Figs 1-4. Chaerilus anneae sp.n., + holotype: 1 - carapace, dorsal aspect; 2 - chelicera, dorsal aspect; 3 - cutting edge of movable finger with rows of granules; 4 - ventral aspect, showing coxapophysis, sternum, genital operculum and pectines.

Pис. 1-4. Chaerilus anneae sp.n., голотип ㅇ: 1 - карапакс, сверху; 2 - хелицера, сверху; 3 - режущий край подвижного пальца с рядами гранул; 4 - вид снизу с изображением коксапофиза, стернита, крышечки гениталий и пектин.

and weakly curved. Pedipalps not elongated; femur with five carinae; internal with a few spinoid granules. Patella with 6 or 7 vestigial carinae. Chela weakly enlarged, with 7 or 8 moderately granular carinae. Tegument moderately granular. Fixed and movable fingers shorter than manus, with 9 and 10 rows of granulations at dentate margins. Chelicerae characteristic of the family Chaerilidae [Vachon, 1963]. Trichobothriotaxy of type B; orthobothriotaxic [Vachon, 1974]; femur with nine trichobothria, patella with 14 , chela with 14 . Legs with pedal spurs moderately developed. Tarsi with two rows of setae. Hemispermatophore unknown. 


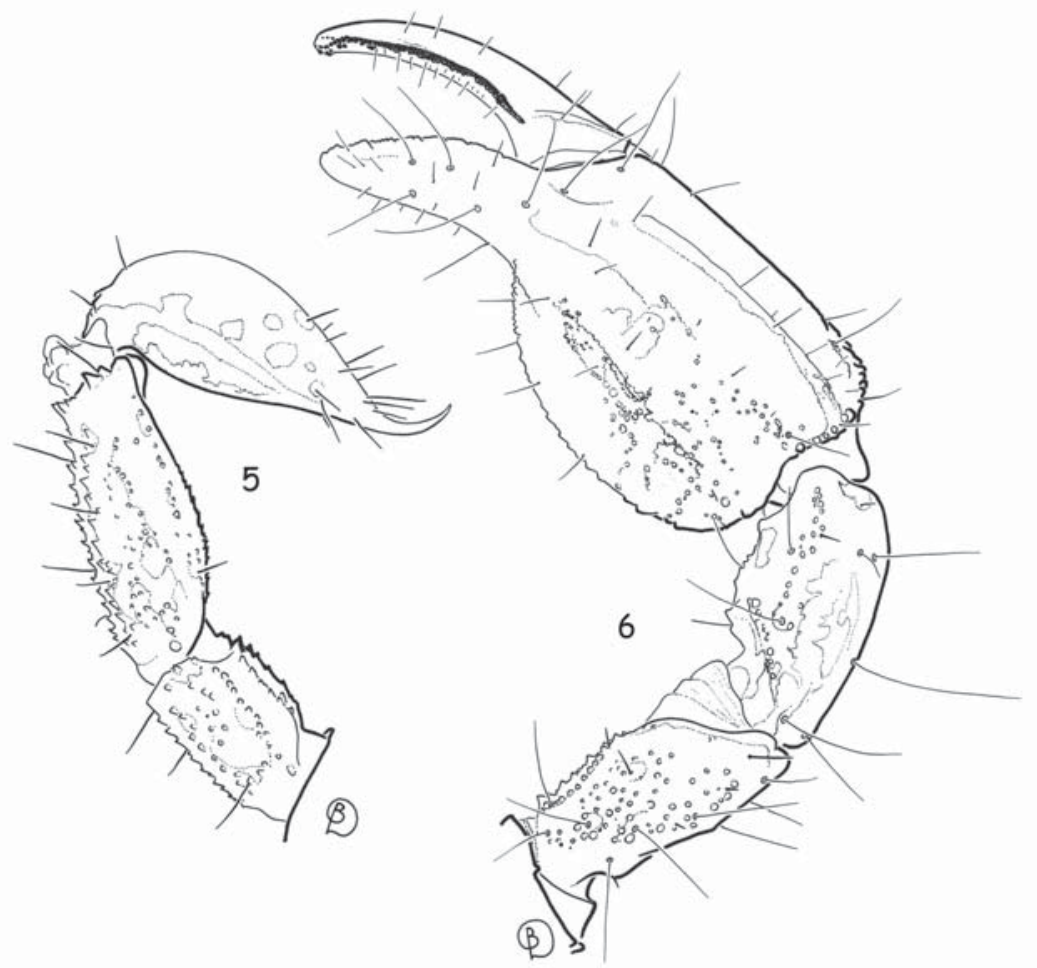

Figs 5 \& 6. Chaerilus anneae sp.n.,, holotype: 5 - metasomal segments IV \& V, and telson, lateral aspect; 6 - right pedipalp, dorsal aspect, showing trichobothrial pattern.

Рис. 5-6. Chaerilus anneae sp.n., голотип +: 5 - сегменты IV и V метасомы и тельсон, сбоку; 6 - правая педипальпа, сверху, с изображением характера распределения трихоботрий.

Morphometric values (in $\mathrm{mm}$ ). Total length (including telson), 18.2. Carapace: length, 2.6; anterior width, 1.5; posterior width, 3.3. Mesosoma length, 6.2. Metasomal segments. I: length, 0.8; width, 1.7; II: length, 1.0; width, 1.4; III: length, 1.1; width, 1.3; IV: length, 1.2; width, 1.2; V: length, 2.4; width, 1.1; depth, 0.9. Telson length, 2.9. Vesicle: width, 1.3; depth, 1.1. Pedipalp: femur length, 2.1, width, 0.9; patella length, 2.2, width, 1.0; chela length, 4.6, width, 1.6, depth, 2.1; movable finger length, 2.2 .

\section{Chaerilus kampuchea sp.n.}

Figs 7-12.

HOLOTYPE O', Cambodia, Kampot Prov., Phnom Laang, near Cave Kien Krol, in litter, Berlese extraction, 20.XI.2005, leg. L. Deharveng \& A. Bedos (KAM05-23).

Paratypes: $1 \sigma^{7}$ juv., 1 juv., same locality, together with holotype.

NAME. The specific name is placed in apposition to the generic name and refers to Kampuchea, the name of Cambodia in the Khmer language.

DIAGNOSIS. A small species compared to other congeners, $13.5 \mathrm{~mm}$ in total length. General coloration yellowish, marked intensely with variegated brownish spots. Carapace strongly narrowed towards anterior edge; acarinate and almost smooth; anterior margin almost straight, without any concavity; furrows shallow. Metasomal carinae moderately marked; ventral carinae absent from or obsolete in segments I and II, weakly marked in segments III and IV; lateroventral and ventral carinae in segment $\mathrm{V}$ composed of spinoid granules. Telson moderately elongated, pyriform; aculeus weakly curved. Dentate margins of fixed and movable fingers with $8-8$ rows of granules. Pectinal tooth count 5-5 $\left(\mathrm{O}^{7}\right)$ or 3-3 ( $)$. Genital operculum plates oval. Trichobothriotaxy of type B, orthobothriotaxic. Hemispermatophore unknown.

RELATIONSHIPS. C. kampuchea sp. n. shows especially clear-cut morphological similarities to $C$. anneae sp.n. and $C$. petrzelkai, both described from Vietnam. However, the new species can readily be distinguished by the following combination of characters: (i) a paler coloration with distinct variegated pigmentation, (ii) less well marked carinae and granulations: carapace and tergites smooth, (iii) pedipalp chela fingers with $8-8$ rows of granulations.

DESCRIPTION. Coloration: Basically yellowish, intensely marked with a variegated brownish pattern. Carapace yellowish, with dark spots anteriorly and laterally. Tergites yellowish with variegated spots. Metasomal segments yellowish with variegated spots. Telson yellowish with diffused variegated spots; aculeus reddish. Chelicerae yellowish with variegated spots, better marked internally; fingers yellowish with dark spots; teeth reddish. Pedipalps yellowish; femur more intensely spotted than patella and chela; fingers dark; 

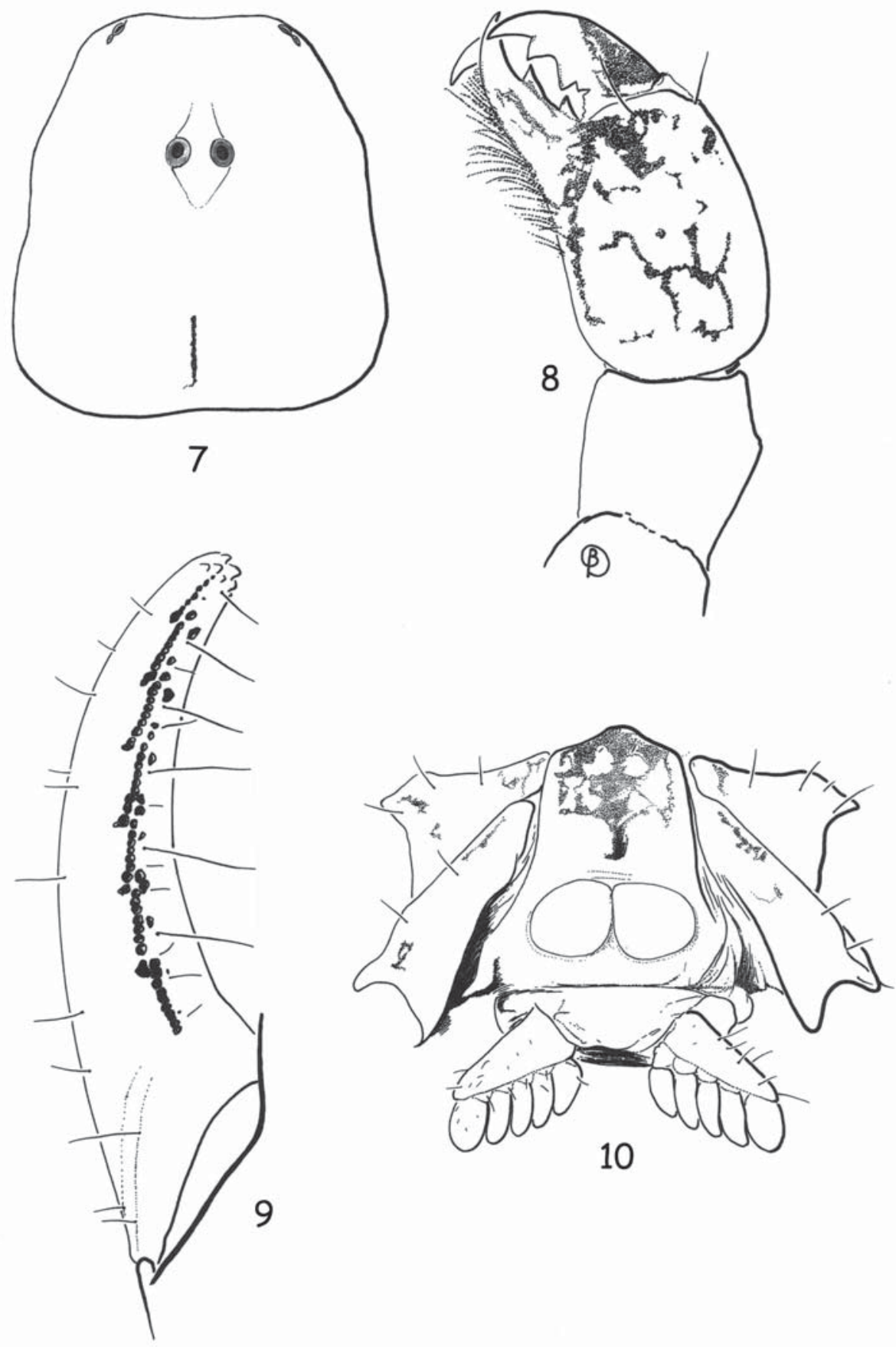

Figs 7-10. Chaerilus kampuchea sp.n., $\bigcirc^{7}$ holotype: 7 - carapace, dorsal aspect; 8 - chelicera, dorsal aspect; 9 - cutting edge of movable finger with rows of granules; 10 - ventral aspect, showing coxapophysis, sternum, genital operculum and pectines.

Рис. 7-10. Chaerilus kampuchea sp.n., голотип О': 7 - карапакс, сверху; 8 - хелицера, сверху; 9 - режущий край подвижного пальца с рядами гранул; 10 - вид снизу с изображением коксапофиза, стернита, крышечки гениталий и пектин.

dentate margins of fingers reddish. Legs pale yellow with diffused brownish spots. Venter and sternites yellowish with some diffused spots; pectines pale yellow.

Carapace strongly narrowed anteriorly; anterior margin almost straight, without any concavity; acarinate and almost smooth, with some minute granulations anteriorly; furrows shallow. Two pairs of lateral eyes, and one pair of large median eyes about twice the size of lateral eyes; median eyes anterior to centre of carapace. Tergites smooth; carinae obsolete. Sternum pentagonal, longer than wide; genital operculum plates oval. Pectinal tooth count $5-5\left(\sigma^{7}\right)$ or $3-3(+)$. Sternites smooth with spiracles small and rounded; carinae absent from VII. Metasomal segments I and II wider than 

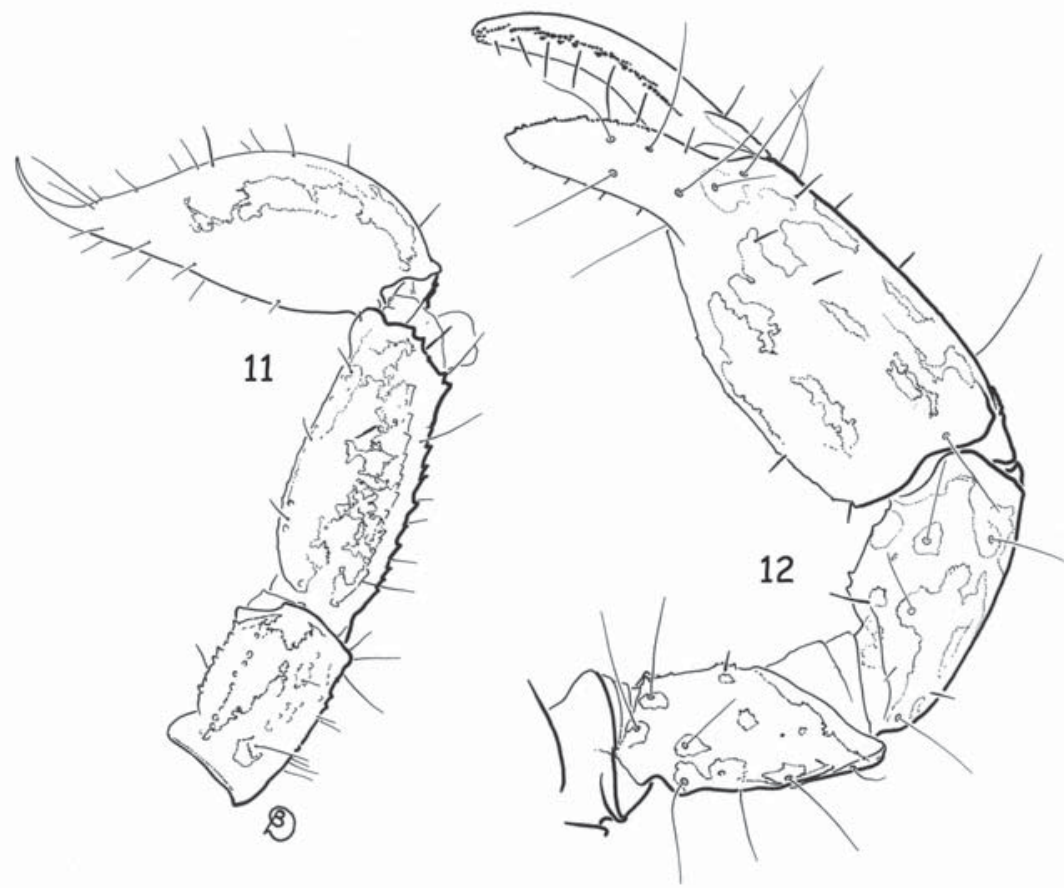

Figs 11 \& 12. Chaerilus kampuchea sp.n., O holotype: 11 - metasomal segments IV \& V, and telson, lateral aspect; 12 - right pedipalp, dorsal aspect, showing trichobothrial pattern.

Рис. 11-12. Chaerilus kampuchea sp.n., голотип O': 11 - сегменты IV и V метасомы и тельсон, сбоку; 12 - правая педипальпа, сверху, с изображением характера распределения трихоботрий.

long; segment III as long as wide; segments IV and V longer than wide. All carinae moderately granular; ventral carinae absent from or obsolete in segments I and II, weakly marked in segments III and IV; lateroventral and ventral carinae in segment $\mathrm{V}$ composed of spinoid granules. Vesicle moderately elongated, pyriform, smooth; aculeus short and weakly curved. Pedipalps not elongated; femur with five carinae; internal without spinoid granules. Patella with vestigial carinae. Chela weakly enlarged and with carinae, weakly granular. Tegument almost smooth, with some minute granulations. Fixed and movable fingers shorter than manus, with 8-8 rows of granulations at dentate margins. Chelicerae characteristic of the family Chaerilidae [Vachon, 1963]. Trichobothriotaxy of type B; orthobothriotaxic [Vachon, 1974]; femur with nine trichobothria, patella with 14 , and chela with 14 . Legs with pedal spurs strongly developed. Tarsi with two rows of spiniform setae. Hemispermatophore unknown.

Fig. 13. Map of Southeast Asia, showing the distribution of the Chaerilus species known from this region: $C$. anneae sp.n. (black triangle); C. julietteae (inverted black triangle); C. kampuchea sp.n. (black asterisk); C. laoticus (black flower); C. petrzelkai (black star); C. phami (black square); C. vietnamicus (black circle).

Рис. 13. Карта Юго-Восточной Азии, показывающая распространение видов рода Chaerilus, известных из этого региона: C. anneae sp.n. (черный треугольник); $C$. julietteae (перевернутый черный треугольник); C. kampuchea sp.n. (черная звездочка); C. laoticus (черный цветок); C. petrzelkai (черная звезда); C. phami (черный квадрат); C. vietnamicus (черный круг).
Morphometric values (in $\mathrm{mm}$ ) of holotype. Total length (including telson), 13.5. Carapace: length, 2.0; anterior width, 1.0; posterior width, 2.0. Mesosoma length, 4.5. Metasomal segments. I: length, 0.6; width, 1.2; II: length, 0.7; width, 0.9; III: length, 0.8; width, 0.8 ; IV: length, 1.0 ; width, 0.7 ; V: length, 1.6 ; width, 0.7; depth, 0.6. Telson length, 2.3. Vesicle: width, 1.0;

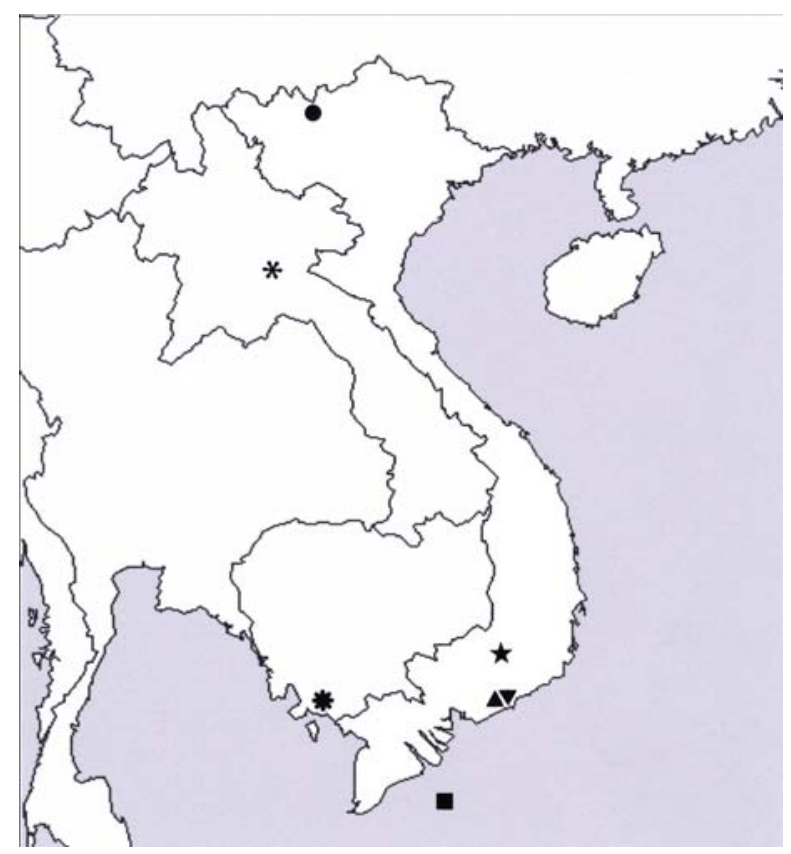


depth, 0.7. Pedipalp: femur length, 1.3, width, 0.8; patella length, 1.5 , width, 0.8 ; chela length, 3.1 , width, 1.0, depth, 1.1; movable finger length, 1.5.

ACKNOWLEDGEMENTS. Material of the two new species described here was collected in fulfilling the project 'Cordillère Annamitique', coordinated by Louis Deharveng (MNHN). The project was funded by the PPF 'Etat et structure de la biodiversite actuelle et fossile' of the MNHM. The field trip to Ta Kou Nature Reserve was organized by Dr. Luu Hong Truong from CDB-ITB (Ho Chi Minh City). Many thanks go also to Bernard Duhem (MNHN), who prepared the illustrations; Elise-Anne Leguin, (MNHN) for the preparation of the plates, and to Prof. John L. CloudsleyThompson, London for comments on and revision of the manuscript.

\section{References}

Fage L. 1933. Les Scorpions de l'Indochine française, leurs af finités, leur distribution géographique // Annales de la Société entomologique de France. T.102. P.25-34

Fage L. 1936. Nouvelle contribution à l'étude des Scorpions de l'Indochine française // Bulletin de la Société entomologique de France. T.41. P.179-181.

Fage L. 1946 (1944). Scorpions et Pédipalpes de l'Indochine française // Annales de la Société entomologique de France. T.113. P.71-80.

Hjelle J.T. 1990. Anatomy and morphology // Polis G.A. (ed.). The Biology of Scorpions. Stanford: Stanford Univ. Press. P.9-63.

Kovařík F. 2000. Revision of family Chaerilidae (Scorpiones), with description of three new species // Serket. Vol.7. No.2. P.38-77.

Kovařík F. 2005. Two new species of the genus Chaerilus Simon, 1877 from Malaysia (Scorpiones: Chaerilidae) // Euscorpius. No.26. P.1-7.

Kraepelin K. 1894. Revision der Scorpione. II. Scorpionidae und Bothriuridae // Beiheft zum Jahrbuch der Hamburgischen wissenschaftlichen Anstalten. Bd.11. S.1-248.

Lourenço W.R. 1995. Chaerilus sabinae, nouvelle espèce de Scorpion anophthalme des grottes de Matampa en Inde (Scorpiones, Chaerilidae) // Revue suisse de Zoologie. T.102. Fasc.2. P. $847-850$.

Lourenço, W. R. 2009. Eyeless forest litter scorpions; a new species from the Island of Halmahera (Moluccas), Indonesia //
Boletin de la Sociedad Entomológica Aragonesa. T.44. P.9397.

Lourenço W.R. 2011a. The genus Chaerilus Simon, 1877 (Scorpiones, Chaerilidae) in Vietnam; description of a new species with comments on possible species-groups // Comptes Rendus Biologies. T.334. Fasc.4. P.337-341.

Lourenço W.R. 2011b. Scorpions from the Island of Côn Son (Poulo Condore), Vietnam and description of a new species of Chaerilus Simon, 1877 (Scorpiones, Chaerilidae) // Ibid. T.334. Fasc. 10. P.773-776.

Lourenço W.R., Duhem B. 2010. One more new species of Chaerilus Simon, 1877 (Scorpiones, Chaerilidae) from the Island of Halmahera, Indonesia // Acta Arachnologica. Vol.59. No.1. P.25-30.

Lourenço W.R., Duhem B., Leguin E.-A. 2011. The genus Chaerilus Simon, 1877 (Scorpiones, Chaerilidae) in the Indian Ocean and description of a new species // Euscorpius. No.110. P.1-8.

Lourenço W.R., Sun D., Zhu M.S. 2010. A new species of Chaerilus Simon, 1877 (Scorpiones, Chaerilidae) from Thailand // The Raffles Bulletin of Zoology. Vol.58. No.1. P.79-85.

Lourenço W.R., Ythier E. 2008. A new species of Chaerilus Simon, 1877 (Scorpiones, Chaerilidae) from the Philippines // Boletin de la Sociedad Entomológica Aragonesa. T.42. P.2731 .

Lourenço W.R., Zhu M.S. 2008. Description of two new species of the genus Chaerilus Simon, 1877 (Scorpiones, Chaerilidae) from Laos and Vietnam // Acta Zootaxonomica Sinica. Vol.33. No.3. P.462-474.

Pocock R.I. 1899. Descriptions of some new species of scorpions // Annals and Magazine of Natural History. Ser.7. Vol.3. P.411420.

Stahnke H.L. 1970. Scorpion nomenclature and mensuration // Entomological News. Vol.81. No.12. P.297-316.

Vachon M. 1963. De l'utilité, en systématique, d'une nomenclature des dents des chélicères chez les Scorpions // Bulletin du Muséum national d'Histoire naturelle, Paris. 2e sér. T.35. No.2. P.161-166.

Vachon M. 1974. Etude des caractères utilisés pour classer les familles et les genres de Scorpions (Arachnides). 1. La trichobothriotaxie en arachnologie. Sigles trichobothriaux et types de trichobothriotaxie chez les Scorpions // Ibid. 3e sér. No.140. (Zoologie. No.104). P.857-958.

Vachon M., Lourenço W.R. 1985. Scorpions cavernicoles du Sarawak (Bornéo). Chaerilus chapmani n. sp. (Chaerilidae) et Lychas hosei (Pocock, 1890) (Buthidae) // Mémoires biospéologiques. T.12. P.9-18.

Responsible editors S.I. Golovatch, K.G. Mikhailov 